\title{
The Urban Museum as a Sustainable Tourism Attraction: London Museum Lates Visitor Motivation
}

\author{
Ayeon Choi, Graham Berridge and Chulwon Kim**
}

\begin{abstract}
The urban museum has become a multi-functional institution that transcends the functional display of artifacts. The museum has become, in cities, a hybrid institution that keeps its doors open late to support a wide variety of special events. This study explored London's 'Museum Lates' programs and event characteristics, using museums' theoretical views as cultural tourism attractions. Furthermore, the study applied the contextual model of learning to understand visitor attendance motivations. Authors employed an interpretive approach using interviews with two types of participants, event visitors, and event coordinators. Findings suggested that attendees possess a complex of personal, physical, and socio-cultural motivations for participating in museum lates events. The characteristics of late events - extraordinary quality and evening time atmosphere - produce different effects than current museum exhibitions held during regular operating hours. Museum lates events can contribute to achieving cultural sustainability, adding cultural construct to the traditional three-pillars of sustainability.
\end{abstract}

Keywords: Museums; special events; late opening; visitors' motivations; sustainability, touristic attractions

\section{Introduction}

Given the mission of the museum to collect, preserve, research cultural artifacts, and use the heritage for educational, study, and enjoyment purposes, the museum plays a pivotal role in shaping the sustainable future (Pencarelli, Cerquetti, \& Splendiani, 2016; Bertacchini, Dalle Nogare, \& Scuderi, 2018). Worts (2006) argued that sustainability is an inherent part of a museum's mission, not only to preserve and enhance cultural heritage and its value but also to contribute to the cultural well-being through programs, e.g., expositions, educational activities, conferences, entertainment events. James and Conaty(2005) supported the museum programs that promote sustainability, such as the adoption of socially responsible behaviors towards new citizens and new generations.

Museum Late events are one of the programs that manage the competitive museum. It was first launched in Berlin, Germany as a tourism event in 1997, called "The Long Night of Museums" (Lange Nacht der Museen) (Gordin \& Dedova, 2014). Since then, similar events have been held in innumerable locations worldwide (Bjeljac, Brankov, \& Lukić, 2011) and a number of cultural institutions in London have held late special events (Kinghorn \& Willis, 2008). For example, various museums have opened their space to the public during after-opening hours to host events, such as "sleep-over" programs and DJ parties (Museumsatnight.org.uk, 2019). Among the many institutions in London, this research focuses on the four main museums: NHM (Natural History Museum), TATE Modern, Science Museum, and V\&A (Victoria \& Albert) Museum. As all four museums have commonly used the term "Lates" to refer to the late special events, this research terms them as 'Museum Lates' (Nhm.ac.uk, 2019; Tate.org.uk, 2019; Sciencemuseum.org.uk, 2019; Vam.ac.uk, 2019).

Despite the increasing popularity of Museum Lates, there has been a lack of relevant academic researches on sustainability. However, some academics have made initial approaches to studying Museum Lates. For instance, Bjeljac, Brankov and Lukić (2011) focused on demographic 
characteristics of Museum Lates visitors. Subsequently, Gordin and Dedova (2014) investigated consumer behaviours of Museum Lates. Mavrin and Glavaš (2014) explored the use of Museum Lates as a promotion modality to attract new visitors. Nevertheless, research gaps exist due to due the paucity of extant research focusing on customer motivation factors for attending Museum Late events. The importance of conducting motivation inquiries in this context has been highlighted by several researchers. Tansuchat and Panmanee (2010), for example, maintain that the understanding of consumer motivation leads to sustainable behavior comprehension and satisfaction enhancement. Therefore, adequate identification of customers' motivations is essential in order sufficiently satisfy customers with different forms of contents (Axelsen, 2006).

Even though people may visit the same location, their motivations could differ, depending on the activity or program they aim to attend and personal preferences (Axelsen, 2006; Falk, 2013). With this cognizance, special events bring unusual and diverse appeal to consumers of the cultural institutions (Axelsen, Arcodia, \& Swan, 2006; Mokhtar \& Kasim, 2011). Moreover, visiting hours may also influence motivation factors (Kinghorn \& Willis, 2008). Consequently, the necessity to identify museum visitors' motivations for attending Museum Lates has been proposed. Previous literature has shown the possibility of distinguishing motivation factors' existence for late events compared with ordinary activities or daytime visits. Consequently, this study aims to discover, analyze, and understand motivations for attending late events focusing on special events and late hours. An inductive approach seems requisite (Saunders et al., 2012; Thomas, 2006) to create a conceptual motivation model of Museum Late visitors. Some qualitative research attempts to discover new motivation factors using interview guidelines and thematic analysis with conceptual classification. Mainly, Axelsen (2006) addressed "Visitor motivations to attend special events in art galleries" by adopting a research concept of Falk and Dierking (1992) 's "the contextual model of learning." The study takes a multi-method qualitative approach to conduct both semi-structured individual interviews with 28 event participants who visited seven separate events at four preselected museums and a focus group interview (FGI) with two event coordinators of NHM.

\section{Literature Review}

\subsection{Museums as a cultural toruism attraction and sustianability}

Conventional roles of museums have been described by several researchers, such as Freeland (2001), Suarez and Tsutsui (2004), including to collect and conserve heritage or masterpieces, and exhibit them to the public. There is considerable evidence that museums' roles have expanded, and utilization of their space has diversified substantially (Cima, 2012; McIntyre, 2009; Mulholland et al., 2011). Hooper-Greenhill (2000) finds that as society keeps changing, the core values of museums are also transforming.

Consequently, today's museums have begun to be recognized as multi-functional institutions (Bjeljac, Brankov, \& Lukić, 2011). Specifically, novel purposes have been incorporated, including education (Hein, 1998; 2005; Deborah, 2004), mass entertainment (Aalst \& Boogaarts, 2002; Getz, 2005; Matthews, 2008), and social interactions (Axelsen, 2006). These new functions seem to constitute vital offerings of today's public museums. Packer and Ballantyne (2002) support this, and identify the existence of increasing expectations toward museums as providers of informal learning and leisure experiences, indicating that the institutions constitute educational leisure sites. Mavrin and Glavaš (2014) focus on the institutions' modernized functions, which are combinations of education and entertainment. It thus seems challenging to distil the roles of museums or determine the specific priority of each role, since museums have largely expanded their types of offerings.

Meanwhile, various researchers claim to include museum in toruism market. (Rowley, 1999; Christianson et al., 2009; Templeton, 2011; Kelley, 2012; falk, 2013; Vassiliadis and Belenioti, 2015). Tourist and leisure entertainment functions of museums have resulted in some debate concerning whether urban museums are primarily heritage conservation organizations or tourist attractions. For example, McIntyre (2009) puts forward a critique of over-commercialization and obvious entertainment direction of museums' public space. Kotler and Kotler (2000) insist that the museums' 
function of exploring the cultural and heritage practices of regions that focus on communities is critical. Nevertheless, they also emphasize the necessity of museums being competitive as entertainment facilities by assuming substantial positions in the tourism market. Aalst and Boogaarts (2002) identify mass entertainment as museums' essential extra function. Indeed, the importance of the entertainment function has continuously increased (Hughes, 2000). Jansen-Verbeke and Rekom (1996) also support museums' attempts to provide additional attractions within cultural tourism and leisure markets.

On the other hand, Pencarelli, Cerquetti, and Splendiani (2016) explore the sustainable management of museums to provide a multi-dimensional model for measuring the museum's environmental, social, and economic sustainability. Merriman (2008) found that sustainability could offer great opportunities for museums, suggesting new ways to interpret and communicate heritage and reach a wider audience, as well as providing innovative and practical solutions to manage collections and relationships with local stakeholders.

The perspectives could be organized as Table 1

Table 1. Researches on museum as touristic and leisure institutions.

\begin{tabular}{cc}
\hline Authors & Perspectives \\
\hline Jansen-Verbeke and Rekom (1996) & the institutions as a part of urban tourist service \\
\hline Kotler and Kotler (2000) & leisure activity market \\
\hline Packer and Ballantyne(2002) & informal learning and leisure experiences, educational leisure sites \\
\hline Falk and Dierking (2012) & leisure context for majority of the audience \\
\hline Merriman (2008) & Sustainability for museum \\
\hline Hein, 2005; Huang and Lin(2013) & educational and amusement \\
\hline Mavrin and Glavaš (2014) & education and entertainment \\
\hline $\begin{array}{c}\text { Pencarelli, Cerquetti, and } \\
\text { Splendiani (2016) }\end{array}$ & sustainable management of museums \\
\hline
\end{tabular}

\subsection{Special events during late hours in museums?}

Gordin and Dedova (2014) referred to Museum Lates as a "special event". A special event has been described as "an external daily program or activity which is either unusually or less frequently hosted" (Getz, 2005). Special events can also exist across varying locations with unusual and/or specific aims: "Specific rituals, presentations, performances or celebrations that are consciously planned and created to mark special occasions or achieve particular social, cultural or corporate goals and objectives" (Allen et al., 2011:11). Consequently, special events could have considered as unique experiences that are beyond daily occurrences. Diversified special events can be held not only during the daytime, but also during late hours to enhance unique experiences (Museumsatnight.org.uk, 2019). Moreover, the traits of late hour events could be differentiated from daytime events (Tansuchat \& Panmanee, 2010).

Hudson (1998) claims that museums have been forced to engage in a process of continual transformation, which has brought the necessity of marketing, as well as commercial and leisure activities. Therefore, museums have become more competitive by considering customer satisfaction as leisure and tourism attractions (Rowley, 1999). Vassiliadis and Belenioti (2015) focus on NPOs as relevant to commercial fundraising and for-profit marketing by stating that, in the role of economic and tourism institutions, museums are finding the need to employ marketing strategies for funding and profit. To achieve this, museums frequently hold additional events that are beyond daily exhibitions (Bjeljac, Brankov, \& Lukić, 2011; Christianson et al., 2009; Kelley, 2012; Cima, 2012). These special events can produce commercial effects, such as profit generation (Kawashima, 1998; Vaughan, 2001). In addition to a new source of profit, special events can contribute to building a museum's image (Vassiliadis \& Belenioti, 2015), promote marketing (Wendroff, 2004), and raise funds as an NPO (Wendroff, 2004).

Overall, special events promote the museum to new and existing customers (Gordin \& Dedova, 2014; Mavrin \& Glavaš, 2014). Bjeljac, Brankov and Lukić (2011) report that late opening hours can 
offer unusual experiences and create new customers (Mavrin \& Glavaš, 2014). Bjeljac, Brankov amd Lukić (2011: 230) assert that the launching of late special events comprises several goals, including to popularize the "cultural tourism and museum complex" and to attract new museums visitors' attention. Similarly, Gordin and Dedova (2014) find that Museum Lates bring new audiences and contribute to the development of novel creative approaches towards organizations. Mavrin and Glavaš (2014) also find that museum nights aim to develop more cultural audiences.

Axelsen, Arcodia and Swan (2006) also maintain that diversification of museums' roles and the development of special events are inherently linked. This is because museums desire to attract more visitors, and the increase of demand for tourist offerings of museums could achieve goal (Julia, 1997). Visitors also increasingly like to have diverse experiences at museums (Kirezli, 2011). Indeed, their senses and experiences are stimulated by combinations of activities during the night (Bjeljac, Brankov, \& Lukić, 2011). Wilburn (2007) also demonstrates that museums can create customer loyalty through marketing processes, including those for Museum Lates. As a result, Museum Lates have developed new visitors and encouraged re-visitation.

Gordin and Dedova (2014) identify Museum Lates as an entrancing experience for visitors, and are typically innovative and inspirational events. Museum Lates can enhance an audience's knowledge, experience, emotion, community spirit, and perceptions towards cultural institutions (Gordin \& Dedova, 2014). According to Kinghorn and Willis (2008), late opening hours also seem to create opportunities for visitors to spend time together, as they are often not able to get together during the working day.

\subsection{Museum visitor motivation research}

Jansen-Verbeke and Rekom (1996) state that adequate comprehension of museum visitors' motivation can assist institutions to obtain pragmatic insight about the institutions' role as an urban tourist service. Investigations of visitors' motivational factors are also crucial because they involve not only expectations, but also behaviour patterns and satisfaction (Packer \& Ballantyne, 2002). Certainly, accurate identification of audiences' needs is essential to deliver fulfilment to them through several types of services (Axelsen, 2006).

However, it may appear difficult to simplify the functions of museums and motivations to attend them since they could differ according the purpose of particular visits. Accordingly, Smith and Wolf (1996) find that museum visitors can be differentiated according to a range of expectations, which can then enable optimal shaping of their experience at the institutions. Since the characteristics of exhibitions, daytime special events, and late opening visits may tend to be dissimilar, corresponding motivational factors might be also diverse (Kinghorn \& Willis, 2008).

Axelsen (2006) identified distinctive visitor motivations to attend museum special events compared to daily exhibitions. The researcher found that visitors taking part in a special event tend to value cultural communication with better engagement and interaction with each other, which might be driven by motivations that differ from those of normal events. Furthermore, the traits of late hour events themselves could be differentiated from those of daytime events (Tansuchat \& Panmanee, 2010). Indeed, extended opening hours might introduce entirely new motivation factors, such as the enhancement of utility (Kinghorn \& Willis, 2008).

\subsection{The contextual model of learning to determine visitor motivation}

Falk (2013) demonstrated certain limitations of conventional division methods for understanding visitor motivations. Falk and Dierking (2000; 2012), therefore, suggest a module to sort museum consumers' learning context, which assists to elucidate different motivation factors. They divide learning sections into three aspects: personal, sociocultural, and physical context. Axelsen (2006) adopted the model to discover museum special events visitors' motivation. 


\subsubsection{Personal Context}

Axelsen (2006: 212-215) includes five different elements under personal contexts, which are learning and education, novelty, previous experiences, professional interest, and specific interest. Packer and Ballantyne (2002) regard the experience of unique conditions as learning; whereas, Axelsen (2006) considers it as novelty. Museums offer educational and amusement experiences to audiences with diverse elements (Hein, 2005; Huang \& Lin, 2013). Packer and Ballantyne (2002) identify self-achievement as an essential motivation factor, which could be a part of education. Considering previous experiences, McManus (1993) claims that memories and feelings from the event also affect the museum visit. In addition, Axelsen (2007) asserts that the professional background of customers could bring new audiences from different industries. Packer and Ballantyne (2002) refer to museums and galleries as educational leisure sites, and conclude that visitors can be motivated by both personal and situational factors.

\subsubsection{Social Context}

Getz and Page (2016) contend that art and entertainment are planned events which are social in nature, which indicates that social motivation is important for making visiting decisions. Sociocultural context motivation comprises a combination of the audience, the institution, cultural aspects, and social engagement (Falk \& Dierking, 2013). Axelsen (2006: 215-216) divides sociocultural context motivations into "social experiences", "family", "recommendations", and "social learning experiences". Packer and Ballantyne (2002) consider spending time with a large number of people from different backgrounds as one category of social context, rather than assigning it to sub-sections. Axelsen (2006) also viewed social experiences (friends, partners, and new people) and family as belonging to distinct categories.

\subsubsection{Physical Context}

Physical context here refers to the surroundings in people's lives, which involve not only accommodated objects, but also the construction and "feel" of a venue (Falk \& Dierking, 2000). Axelsen (2006: 217) analysed physical context as two sub-elements, which are special events and atmosphere. However, he also identified the importance of comfort as a part of physical context motivation factors to visit museums. Hooper-Greenhill (1994:6) also states, "A physical experience using all the senses is called for." Research has also been performed on the physical settings of events. Nelson (2009: 126-129) identified the following physical elements: "ambient condition, atmospheric/ service scape, music/ aroma, room temperature, props, décor, lights/ AV/ sound/ special effects, costumes, and room layout/ functionality". Kinghorn and Willis (2008) identify late hour openings and venue environments, respectively, as important themes which could bring new motivations to visitors. Getz (2005) defines a special event as an external daily program or activity that is unusually held. Axelsen (2006) claims that a special event itself could possibly be a motivation factor for customers to visit museums.

\section{Methodology}

\subsection{Research aim and questions}

This study aimed at discovering and clarifying new motivation factors for visiting Museum Lates in London. There are six main research questions to probe which have been generated from reviewing previous researches.

1. How visitors can be clarified according to Identity-related motivational factors?

2. What are the motivational factors for consumers to visit the Museum Late?

3. How are the motivations different comparing with other daily activities and exhibitions?

4. How are the motivations different comparing with day-time and late-hour visit?

5. Can the Museum Late itself be a motivational factor?

6. Why the Museum Late is important for museums as multi-functional institutions 


\subsection{Qualitative methodology approach}

In order to explore the research purpose and questions, inductive approach has been adopted as the most adequate research method since there have not been enough motivation researches on Museum Lates (Thomas, 2006).

The reasons for adopting qualitative approach was:

1.To comprehend motivational factors as a part of life-world of social science (Berg and Lune, 2012).

2.Research enquiries were to be investigated with open-ended questions rather than closed questions

(Saunders et al., 2012).

3.To probe the complex motivations needed narratives from visitors' stories (Axelsen, 2006).

The validity of the methodology is confirmed by Berg and Lune (2012:3), who assert that qualitative research can be designed to ask "what, how, when, where, and why" questions, and thus aims to understand "the meanings, concepts, definitions, characteristics, metaphors, symbols, and descriptions of things" from an individual's subjective perspective. Entire interviews were conducted through face-to-face interviews in order to obtain information from social cues, which include body language, vocal intonations, and etc. (Opdenakker, 2006). Furthermore, research enquiries were to be investigated with open-ended questions (Saunders et al., 2012) to probe complex motivations from visitors' stories (Axelsen, 2006). The approach is known to be effective when creative self-expression of the individual is requisite which can be employed to discern new motivation factors for visiting Museum Lates.

\subsection{The interview guide and pilot study}

Semi-structured interviews have been conducted having determined interview guidelines and analyse themes (Collier \& Elman, 2008; Saunders et al., 2012). The module of Axelsen (2006: 213), "visitor motivations to attend special events in art galleries" was applied to create the interview guidelines.

Turner (2010) demonstrates the necessity of performing a pilot study in advance of actual data collection. In order to reduce data quality concerns, a pilot study was carried out amongst a small sample of acquaintances of the researcher who had visited Museum Lates before the data collection. In total, three pilot interviews were performed, and interview guidelines were fixed, and voice recordings were tested

\subsection{Sampling and Data Collection}

After the pilot study, the primary data have been collected from two different categories of respondents: event visitors and event coordinators. Individual interviews on visitors and focused group interviews (FGIs) on field experts have been performed. As shown in Table 2, 30 interviewees participated in total including 28 visitors and two event coordinators who visited seven different night events held in four separate museums in London. The number of interviewees has been considered to minimize data quality issue, since Saunders et al. (2012) suggested that the smallest sample size of a semi-structured interview should be between 5 and 25 with the intention to perform data collection until a new perspective identifies.

Table 1. Research Scope

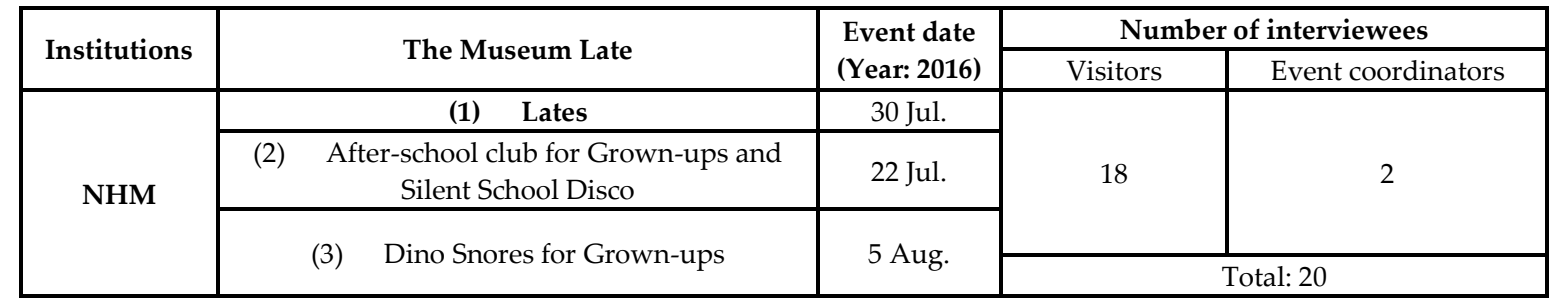




\begin{tabular}{|c|c|c|c|c|}
\hline $\begin{array}{c}\text { Science } \\
\text { Museum }\end{array}$ & (4) Lates: Power Up & 27 Jul. & 5 & 0 \\
\hline $\begin{array}{c}\text { Tate } \\
\text { Modern }\end{array}$ & (5) Tate Tap Takeover & $28 \mathrm{Jul}$. & 5 & 0 \\
\hline \multirow{2}{*}{$\begin{array}{c}\text { V\&A } \\
\text { Museum }\end{array}$} & (6) Friday Late (Oct. 2015) & $\begin{array}{l}30 \text { Oct. } \\
2015\end{array}$ & 1 & \multirow[t]{2}{*}{0} \\
\hline & (7) $\quad$ Friday Late (Apr. 2016) & 29 Apr. & 1 & \\
\hline Total & & & 28 & 2 \\
\hline
\end{tabular}

In general, qualitative sampling needs to be both flexible and practical (Marshall, 1996). Heterogeneous sampling and purposive sampling were chosen for event visitors and event coordinators, respectively. The reason was because the research aims to indicate and guide core themes, and possesses its own criteria for systematically handling the contents of samples (Saunders et al., 2012). For sampling of event coordinators, NHM was purposively selected as the respondents of FGI since the events in the organizations occupied a central aspect in this investigation as shown in table 3 (White \& Marsh, 2006).

Table 2. Focus group interview (FGI) respondents' details.

\begin{tabular}{cccc}
\hline Code & Organization & Position & Interview style \\
\hline EC-1 & NHM & Senior Event Coordinator & Semi-structured \\
EC-1 & NHM & Senior Event Coordinator & FGI \\
\hline
\end{tabular}

EC: Event Coordinator

Purposeful sampling is the most commonly utilized, especially when advancing a framework based on individuals' viewpoints, researchers' backgrounds, and relevant literatures (Marshall, 1996). For sampling visitors, attempts to explore a similar ratio of gender, and a wide range of age, nationality, and companions were made (see table 4). This was not done to identify themes for analysis, but rather to understand the motivation of visitors and to minimize data quality issues. The durations of each interviews on visitors were from $5 \mathrm{~min}$ to $30 \mathrm{~min}$.

Table 3. Individual interview respondents' details.

\begin{tabular}{|c|c|c|c|c|c|}
\hline Code & Nationality & Gender & Occupation & Age & Companion \\
\hline R-1 & Japanese & M & Student & $30 \mathrm{~s}$ & Friends \\
\hline R-2 & British & $\mathrm{M}$ & Working & $30 \mathrm{~s}$ & Friends \\
\hline R-3 & American & $\mathrm{F}$ & Student & $10 \mathrm{~s}$ & Alone \\
\hline R-4 & British & $\mathrm{M}$ & $\begin{array}{c}\text { Working } \\
\text { (entertainment } \\
\text { Industry) }\end{array}$ & $20 \mathrm{~s}$ & Friends \\
\hline R-5 & American & $\mathrm{M}$ & Working & $30 \mathrm{~s}$ & Alone \\
\hline R-7 & British & $\mathrm{M}$ & $\begin{array}{c}\text { Working } \\
\text { (art industry) }\end{array}$ & $30 \mathrm{~s}$ & Co-workers \\
\hline R-8 & Canadian & $\mathrm{M}$ & $\begin{array}{c}\text { Working } \\
\text { (art industry) }\end{array}$ & $30 \mathrm{~s}$ & Co-workers \\
\hline R-9 & British & $\mathrm{F}$ & $\begin{array}{c}\text { Working } \\
\text { (art industry) }\end{array}$ & $70 \mathrm{~s}$ & Friend \\
\hline R-10 & British & $\mathrm{F}$ & $\begin{array}{c}\text { Working } \\
\text { (art industry) }\end{array}$ & $60 \mathrm{~s}$ & Friend \\
\hline R-11 & Italian & $\mathrm{F}$ & Tourist & $30 \mathrm{~s}$ & Partner \\
\hline R-12 & Czech & $\mathrm{M}$ & Tourist & $10 \mathrm{~s}$ & Mother \\
\hline R-13 & Czech & $\mathrm{F}$ & Tourist & - & Son \\
\hline R-14 & British & $\mathrm{F}$ & Working & $30 \mathrm{~s}$ & Son and Friends \\
\hline R-15 & British & $\mathrm{M}$ & Working & $30 \mathrm{~s}$ & Friends \\
\hline R-16 & British & $\mathrm{M}$ & Working & $20 \mathrm{~s}$ & Sister \\
\hline R-17 & Korean & $\mathrm{M}$ & Tourist & $40 \mathrm{~s}$ & Family \\
\hline
\end{tabular}




\begin{tabular}{|c|c|c|c|c|c|}
\hline R-18 & British & $\mathrm{M}$ & Working & $20 \mathrm{~s}$ & Friends \\
\hline R-19 & Canadian & $\mathrm{F}$ & Tourist & $20 \mathrm{~s}$ & Friends \\
\hline R-20 & British & M & Working & $40 \mathrm{~s}$ & $\begin{array}{c}\text { Social club } \\
\text { members }\end{array}$ \\
\hline R-21 & Chinese & $\mathrm{F}$ & $\begin{array}{c}\text { Student } \\
\text { (event major) }\end{array}$ & $20 \mathrm{~s}$ & Friends \\
\hline R-22 & Thai & $\mathrm{F}$ & $\begin{array}{c}\text { Student } \\
\text { (event major) }\end{array}$ & $20 \mathrm{~s}$ & Friends \\
\hline R-23 & Taiwanese & $\mathrm{M}$ & Student & $20 \mathrm{~s}$ & Friends \\
\hline $\mathrm{R}-24$ & British & $\mathrm{F}$ & Working & $40 \mathrm{~s}$ & Partner \\
\hline R-25 & Finn & $\mathrm{F}$ & Student & $20 \mathrm{~s}$ & Alone \\
\hline R-26 & British & $\mathrm{F}$ & Working & $50 \mathrm{~s}$ & Friend \\
\hline R-27 & British & $\mathrm{F}$ & Working & $40 \mathrm{~s}$ & Friend \\
\hline R-28 & Chinese & $\mathrm{F}$ & $\begin{array}{c}\text { Student } \\
\text { (event major) }\end{array}$ & $20 \mathrm{~s}$ & Friends \\
\hline
\end{tabular}

$\mathrm{R}$ : Respondents

\subsection{The Analysis}

In order to analyse the collected primary data, voice-recorded data were transcribed into text. As the next stage, text coding has been conducted for each interviewee and contextually recategorized into adequate themes (Bryman, 2016). To be more specific, data were analysed with thematic networks which consist of basic themes, organizing and global themes (Attride-Stirling, 2001). The "Visitor motivations to attend special event events in art galleries" module of Axelsen (2006: 213), which adjusted "The contextual model of learning" (Falk \& Dierking, 1992), was used for discovering and analysing motivations to attend the Museum Lates. In qualitative research, meanings are mainly found from linguistic expression, and not from numerical value (Saunders et al., 2012). Consequently, clarification of different meanings of a word should be approached sensitively for a clear understanding. In order to illuminate the data in the form of text, thematic analysis employed (Attride-Stirling, 2001).

\section{Findings and Analysis}

\subsection{Contextual motivation factors}

When asked to explain their motivations in detail, the visitors provided diverse responses. Some expressions were given with different vocabulary with the same or similar meanings. Therefore, the factors were analysed from interviewees' overlapping or new expressions within the record according to theoretical themes. During the process, this paper detected some similarities and differences on contextual motivation factors compared to the applied theories: "contextual model of learning" of Falk and Dierking $(2000 ; 2012)$ and "Visitor motivations to attend special events in art galleries" of Axelsen (2006). Three different upper themes: personal, sociocultural, and physical context have been matched. However, new themes have been found, which were combined context and comparison context (Figure 1). As shown in Figure 2, explored motivations have been categorized into applicable themes more in detail. 


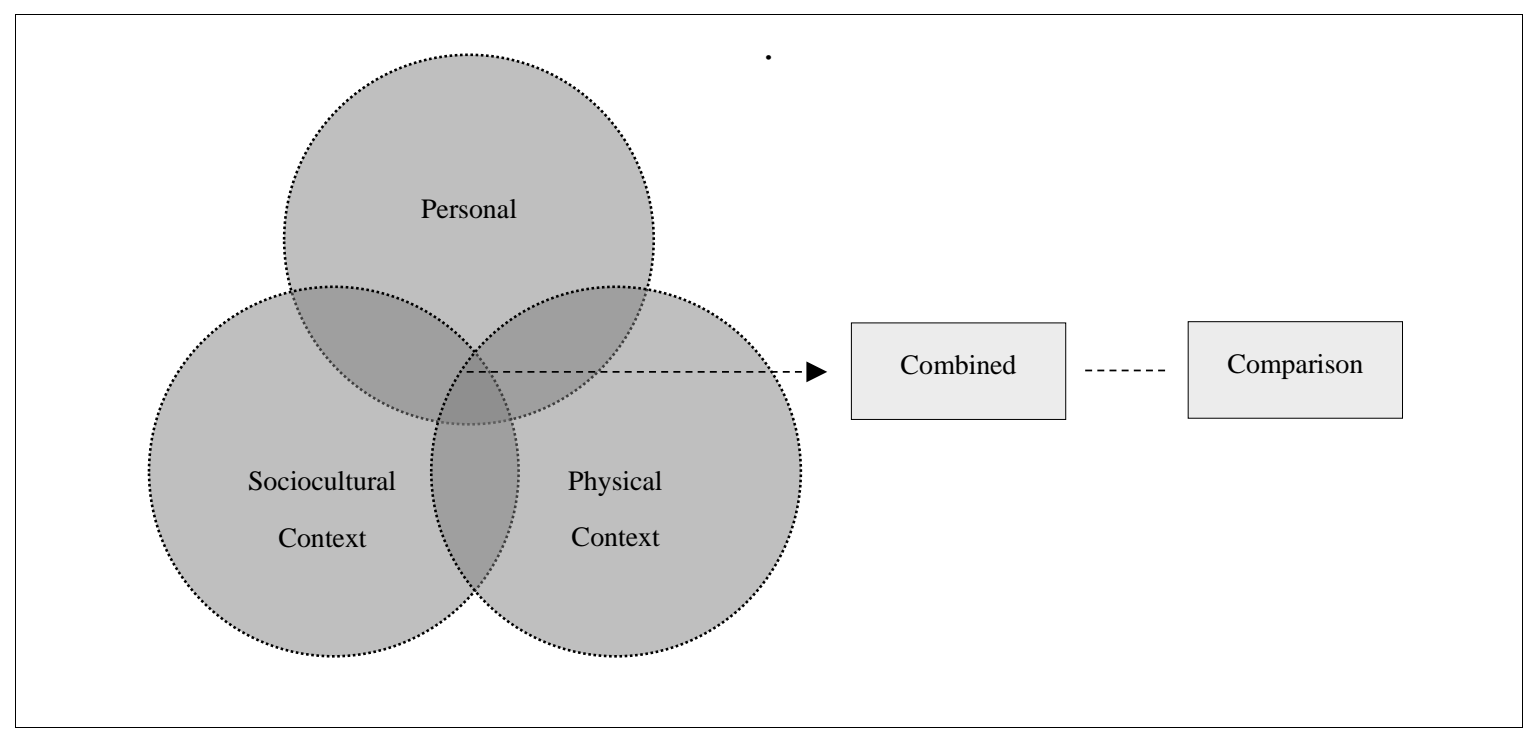

Figure 1. The contextual model of motivation to visit Museum Lates. 


\begin{tabular}{|c|c|c|}
\hline Personal Context & Social Context & Physical Context \\
\hline $\begin{array}{l}\text { Learning and Education } \\
\text { - Learn in detail } \\
\text { - Better concentration }\end{array}$ & $\begin{array}{l}\text { Social Experiences } \\
\text { - New people with same interest } \\
\text { - Spend time with friends }\end{array}$ & $\begin{array}{l}\text { Special events } \\
\text { Silence disco } \\
\text { Sleeping over programme }\end{array}$ \\
\hline $\begin{array}{l}\text { Novelty } \\
\text { - Uniqueness } \\
\text { - Something new / Curiosity } \\
\text { Something gpecial }\end{array}$ & \multirow{2}{*}{$\begin{array}{l}\text { - Sibling } \\
\text { - Mother } \\
\text { - Son } \\
\text { - Children } \\
\text { - Partner }\end{array}$} & \multirow{2}{*}{$\begin{array}{l}\text { Lightning Atmogphere } \\
\text { Colourful } \\
\text { Decoration } \\
\text { Beautiful building } \\
\text { Music }\end{array}$} \\
\hline \multirow{3}{*}{$\begin{array}{l}\text { Previous Experiences } \\
\text { - Experience from other } \\
\text { organization } \\
\text { - Experience from game } \\
\text { organization } \\
\text { - (Childhood) memories in the } \\
\text { particular museum }\end{array}$} & & \\
\hline & $\begin{array}{l}\text { Recommendation } \\
\text { - From friend } \\
\text { - From colleague } \\
\text { - family }\end{array}$ & $\begin{array}{l}\quad \text { Late Opening Hours } \\
\text { After-work } \\
\text { After-9chool }\end{array}$ \\
\hline & \multirow{3}{*}{$\begin{array}{l}\quad \text { Marketing } \\
\text { Attracted from online marketing } \\
\text { Facebook page } \\
\text { E-letter } \\
\text { - Poster } \\
\text { - Local magazine } \\
\text { - Social platform }\end{array}$} & \multirow{2}{*}{$\begin{array}{l}\quad \text { Convenience } \\
\text { - Less crowed } \\
\cdot \text { Less children } \\
\text { - Less tourists }\end{array}$} \\
\hline \multirow{3}{*}{$\begin{array}{l}\text { Profeggional Interest } \\
\text { - A part of museum culture } \\
\text { - Industrial life } \\
\text { - Benchmark other museum } \\
\text { - Extension of work } \\
\text { - To gee the right direction }\end{array}$} & & \\
\hline & & \multirow{3}{*}{$\begin{array}{l}\text { - London Venue } \\
\text { - Space } \\
\text { - Building } \\
\text { - Scenery } \\
\text { - Architecture } \\
\text { - Easy access } \\
\text { - Loyalty toward institution }\end{array}$} \\
\hline & \multirow{2}{*}{$\begin{array}{l}\text { Social Learning Experiences } \\
\text { - Professional networking } \\
\text { - Sharing knowledge }\end{array}$} & \\
\hline \multirow{2}{*}{$\begin{array}{l}\text { Specific Interest } \\
\text { A part of museum culture } \\
\text { - Industrial life } \\
\text { - Benchmark other museum } \\
\text { - Extension of work } \\
\text { - Specific interest in such attraction }\end{array}$} & & \\
\hline & & \\
\hline Feel Special & & \\
\hline $\begin{array}{l}\text { Fun Entertainment } \\
\cdot \text { Enjoyment } \\
\text { - Drink }\end{array}$ & & \\
\hline Relax after work & & \\
\hline \multirow{2}{*}{ - Site-seeing } & & \\
\hline & 1 & \\
\hline & Combined Context & \\
\hline - Combinations & Complex $\underline{\mathrm{Mix}}$ & \\
\hline
\end{tabular}

\begin{tabular}{|c|c|}
\hline \multicolumn{2}{|c|}{ Comparison Context } \\
\hline $\begin{array}{l}\text { Time: } \\
\text { Daytime / Night time } \\
\text { Contents: } \\
\text { Daily events / Special events } \\
\text { Exhibition / Special events }\end{array}$ & $\begin{array}{l}\text { Difference } \\
\text { Place: } \\
\text { Other heritage and tourist attraction / museum } \\
\text { Other leisure venue / museum } \\
\text { Other educational venue / museum }\end{array}$ \\
\hline
\end{tabular}




\subsubsection{Personal context}

Each individual possesses his or her personal context motivation, and stated reasons for attending Museum Lates were diverse. Relevant to the characteristics of Museum Lates, different personal context motivation factors other than those suggested by Axelsen (2006) have existed. First, entertainment, enjoyment, and recreation seem to be extremely important motivations (Packer \& Ballantyne, 2002). Secondly, an additional element would be relaxation, which refers to the anticipation of recovery and restoration with direct mentioning of "relaxation". Furthermore, "siteseeing" was another crucial motivation factor of tourists.

In addition, personal feelings have been expressed, in that with expectation of to "feel special" being inside the venue during special hours with a limited number of people, and that it gives her a sense of superiority. Moreover, Mokhtar and Kasim (2011) maintain "a specific interest in such attraction" as a motivation to visit museums.

Personal context constituted a global theme, with various organizing and basic themes (AttrideStirling, 2001). Moreover, the major theme, "learning and education", had diverse comments in comparison with "entertainment" by most of the interviewees. There was a tendency within the visitors' expectations for experiencing something extraordinary by mentioning "uniqueness", "something new", and "something special" which were thematically analysed into "novelty" category. "Previous experiences" was another important theme for Museum Late motivation. As a representative quotation, R-26 mentioned:

".. I was brought here as a child and I had such good memories... that to come back as adult and spend a night here is truly magical."

Continuously, "specific interest" was emphasized by several respondents with expression like, "simple interest", "superiority" and "professional interest". Similarly, when event coordinators of NHM were asked the same question, both EC-1 and EC-2 set "benchmarking" as their priority motivation. Moreover, "personal interest" and "to see if we are going on the right direction" were identified as their motivations. Some participants who were working outside of the art industry during the daytime had specific demands for "entertainment" and "relaxation". For example, leisure appeal of museums as after-work rechargers have been highly evaluated. Meanwhile, participants working in the art industry, highly evaluated "professional interests".

\subsubsection{Sociocultural context}

As Hooper-Greenhill (1994) and Allen et al. (2011) demonstrate, sociocultural factors seem to be prominent characteristics of special events in museums because diverse and specified expectations were mentioned. Differences in specific themes of cultural aspects and social engagement were found, especially from facilitators who were spending time with friends (Falk \& Dierking, 2013). Companions constituted another crucial factor for understanding identity-related motivation. Visitors who were with friends or part of a social club especially emphasised "socializing" with "friends" and "new people" as facilitators.

Within the sociocultural context, expressions to describe social experiences were articulated by several respondents "spend time with friends"; "meet new people with same interest"; "Family". In terms of recommendations, "invited from my friend" and "introduced by friend", respectively. Recommendation have been noted with direct expression, "my manager recommended". In addition to Axelsen's (2006) categories of organizational promotions into recommendations, visitors distinguished motivations as "recommendations" from acquaintances and "marketing" of museums. Marketing have been found as another important motivation, "online marketing", "newsletter", " $e$ mail", "poster", "local magazine", "Facebook page". Factors consisting of "social learning experiences" were mentioned, as well. That includes "networking", "to meet the people who were in a part of our general professions", "sharing knowledge". 


\subsubsection{Physical context}

The key finding of physical context was special late-opening hours, convenience, and venue (in London), other than special events as determined by Axelsen (2006). As part of physical context, participants said that the "special events" particularly, "silent disco" and "sleeping over programme". Moreover "atmosphere" was frequently mentioned as another crucial motivation. Continuing interviewee's expression with, "late opening hours", extended opening hours was mentioned by many visitors as their motivation to visit Museum Lates. For example, interviewees repeatedly emphasised the word "night" and also mentioned "especially at night" as the motivation factor. Similarly, "after work" and "opening hour" as motivations have been emphasized. R-3 described museum visits after work, stating:

“(...) normally the opening hours of museum are very close to when I work, so I don't get much time to go to museums during the day."

"Convenience" was identified as another factor with supporting statements, "limited number of people" and "without tourists" which have been interpreted as "less crowed". Specifically, "Less touristic" and "less children" were identified during late hours.

Regarding loyalty toward the "venue", there were motivations such "a specific interest in such attraction", as well, which was categorized in both physical contexts. Regional factor venue, "London" was another physical context motivation which was mentioned by several visitors with British nationality. Some foreign interviewees also mentioned the regional factor.

\subsubsection{Combination and complexity}

Due to complexity (Axelsen, 2006) in the special events and the additional speciality of late hours (Mavrin \& Glavaš, 2014), the motivations were also complex. Combined factors were also indicated by using direct words, as R-18 emphasised combination by mentioning "my motivation to come to this late event is a set of combinations" , R-19 stated "it is a good mix, the visiting motivation is not simple", and R-14 also mentioned "the reason to come here is mixed". As museums are considered to be multi-functional institutions with diverse services and programmes, some visitors valued different expectations equally. The motivation for museum visits is becoming increasingly complex with the rising complexity of museum offerings (Axelsen, 2006).

\subsubsection{Comparisons}

\subsubsection{Other daily activities and exhibitions}

Respondents compared Museum Lates' motivation factors with other daily activities and exhibitions. According to EC-1, Museum Lates have different aspects compared to daily activities:

"The Lates are a great way to open our door to people who are interested in learning more about museum and what is happening here, day to day is quite different setting (...)"

When visitors were asked if there were differences in motivations to visit ordinary activities and Museum Lates, R-16 stated:

"So, for me, tonight is more about enjoying the space, but not necessarily seeing the exhibitions. It's a beautiful building, so I'll have a drink with my sister and catch up in beautiful scenery."

Several respondents mentioned that daily activities and special events possess a contrast of "education" and "uniqueness", in which daily activities were motivated by education, while special events were motivated by uniqueness. 


\subsubsection{Daytime}

Compared to daytime visits, respondents stated "night is special" and compared the different visiting hours in personal, social, and physical contexts as "education during daytime, not during night", "meeting new people" is more expected during night.

"(...) the atmosphere is just not that educational, you know, lighting is so colourful and the decoration and people talk and laugh is just more entertainment, is not that educational." R-21

So, the difference in motivation during night time could possibly be situated in all three contexts (Kinghorn \& Willis, 2008; Falk \& Dierking 2000). Better engagement was emphasised as the difference between daytime and night time visits by both event coordinators and visitors. Several visitors stated that the late opening hour motivations are distinct from daytime visiting. R-22 describes "late opening hours" as making the event more special:

“(...) I think that's the main point (nodding). It made the museum night special (...) It is not really common for museum to be opened during night time, so it makes [the event] more special, the event in the night time. I think I prefer during night time because maybe I am a student, so I after full day study or if I am working you know [I will] definitely want to do something with my friends and want to be relaxed, yes uh huh (nodding)."

Moreover, concerning convenience of physical context, interviews mentioned "less tourists during night" and "daytime is full of tourist"; "less crowded", "less kids, you must have seen all the kids if you come during day times", and "can focus better." When the senior event coordinators of NHM were asked if there was a difference in late events and day time events, EC-1 answered:

"Day time events are quite structured, quite short (...) level of depth of engagement is different. (...) the topics and contents are the same but running hours and the level of engagement is different".

\subsection{Museums as multi-functional institutions}

Linked with the debate about diversified museums' roles, a controversy also exists between education and entertainment as motivations. R-7 said:

"Though I came during night and having drinks, educational and professional reasons come preferentially."

Similarly, there was mentioning about multi-functions of museums R-11: "attracting is important but education is more crucial." Meanwhile, tourist and leisure functions were mentioned by many visitors. For example, several visitors valued entertainment more than education. R-20 stated "(my motivation is) not education, but entertainment." Concerning circumstances, it seems difficult to define which one is a superordinate to the other. The statement, "Museum can be anything." (EC-2) expressed the unlimited potential of museum functions. In terms of the functions of museum, EC-2 states:

"I think people's expectation is constantly growing... some people do not consider, not everyone but, as the same old dusty institutions they used [be], they are much more opened, places to talk, discuss ideas ... I think people see there as more of almost like a theme park or a festival so our events are also almost considered to be in the bracket as well, the field is completely opened as the next, Museum can be anything."

There were also visitors who were aware that museums played various roles as multifunctional institutions. For example, R-4 stated: 
“I guess [museum's role is] a part for research and a part for entertainment, isn't it? And sort of yes comes together as well."

\subsection{Museum Lates as a motivation}

The question of whether or not Museum Lates themselves were visitors' motivations was not posed. However, there were several main words that could be interpreted as keywords to describe Museum Lates by almost every participant, such as "Special", "cool", "unique", "unusual", "interesting", and "New". Moreover, numerous motivations were to experience uniqueness. Axelsen (2006) demonstrates that special events in themselves could possibly constitute a motivation factor for customers to visit museums.

\subsection{The importance of Museum Lates}

As determined from the extant literature, developing new audiences in various targeted segments (Bjeljac, Brankov, \& Lukić, 2011), marketing (Wendroff, 2004), and branding (Vassiliadis \& Belenioti, 2015) were mainly found as the essential roles of Museum Lates by opening their "door to the people" (EC-1). An issue relevant to commercial fundraising of NPO (Vassiliadis \& Belenioti, 2015) was mentioned by EC-2:

"...um everything really does with that um generating income generating some revenue for the museum as well through tickets...it is needed for the institution, but we do not expect big profit from the event."

As Kawashima (1998) and Vaughan (2001) assert, the rise in fundamental profit from special events is essential for museums.

Distinct factors were also discovered in terms of engagement. Specifically, engaging audiences with the museum and activating engagement (Weil, 1997; Hein, 2005) amongst different audiences were highlighted by event coordinators and visitors, respectively. Among visitors, encouraging revisitation was the major effect of Museum Lates, more than attracting new audience. For instance, R2 said "If you don't have a cool event to make it, the novelty will wear off." This could be considered alongside culture consumers' increasing expectations, as they demand a better and diverse appeal from museums (Axelsen; 2006).

Both event coordinators emphasized engaging of the audience with the venue and developing different target audiences. When asked to identify the purposes of Museum Lates, the event coordinators stated:

"They primarily started off as another way of engaging different audiences that wouldn't come naturally during the day or on the weekend do something that's fun that's interesting that's exciting for a completely new market segment(...) They are amazing more fun time to get closer to the public" (EC-1).

“(...) I would say in terms of the rest of our events and currently our objectives are kind of around um as Eszter said developing new audiences and engaging them with our sites and the collections...I would defiantly say, across event, we are targeting similar but slightly different people bring into museum...inspiring people for learning... It is a good hook; some might not be coming otherwise" (EC-2).

Similarly, some visitors mentioned why Museum Lates are important for the institution. Firstly, R-4 pointed out "Engaging different audiences" as a crucial factor. Subsequently, "new audience development", was identified as the main purpose of Museum Lates from several literatures, as well as R-4 and R-15. Museum Lates were also highlighted as a method for encouraging re-visitation by $\mathrm{R}-2$ and R-11: 
"Cool event is crucial for current museums to hook visitors to come back. Simply drinking and partying can hardly lead to revisit of consumers" (R-2).

"If [they] have always the same things, you don't want to come more than once, I think. If you change something and [they] give something new, people would like to come again, maybe"(R-11). R-28 also mentioned Museum Lates as a "marketing" method of museums.

\section{Conclusion}

In conclusion, museums' diversified roles have resulted in complexity in institutional characteristics, which have produced several controversies. Not only education but also leisure and tourist appeals have become essential functions beyond their everyday tasks. Therefore, consumers and organizers seem to be aware of existing complicated expectations towards museums. Moreover, people generally demand to experience diverse offerings from museums that are educational or entertaining but have achieved special appeals of their own, which could hardly be compared to other entities in the education or tourism markets. Numerous researchers, including Merriman (2008) and Pencarelli, Cerquetti, and Splendiani (2016), have identified sustainable museum management to interpret and communicate heritage, reach a wider audience, and provide innovative and practical solutions to manage collections and relationships with local stakeholders. Consequently, museums can be multi-functional institutions to achieve sustainability, emphasizing the environmental, socialcultural, and economic dimensions.

The study investigated the motivation factors to attend Museum Lates through collecting and analyzing primary data in three separate themes: personal, sociocultural, and physical. The theory from "Visitor motivations to attend special events in art galleries" (Axelsen, 2006) adapted from "The contextual model of learning" (Falk \& Dierking, 1992) was applied. The study found that all three themes linked to each other in discovering visitors' motivation factors. Overall, the findings of this research matched well with the adopted model and theory. A novel result also revealed that a combined context of personal, sociocultural, and physical context was a crucial motivation to visit Museum Lates.

The findings show that several visitors who expressed satisfaction from "previous experience" were willing to explore different Museum Lates of several institutions in London. Among them, visitors with loyalty toward Museum Lates were expecting advancement of contents and themes, rather than the simple concepts of drinking and DJ parties. It found a tendency characterized by strong demand for something unique and exciting that could stimulate their different senses and desire for novelty. Museums are institutions that exist for society and the public (DiMaggio, 1996; Kinghorn \& Willis, 2008; Hein, 2005). Consequently, engagement with the public and society seems fundamental for museums (Weil, 1997; Hein, 2005; Sandra \& Eduardo, 2018). Axelsen (2006) maintains that social patterns and demands influence recent museum trends. As a result, possessing a streamlined strategic approach to vitalize engagement with society is required for museums (Bradburne, 2001). Indeed, beyond the distinct satisfaction of entertainment, education, and socialization, an adequate combination seems to be requisite.

One of the main findings was that the extension of opening hours and specified target audiences constituted another motivation of convenience. Museum Lates' main uniqueness was a provision of combined activities other than ordinary exhibitions and programs during extended opening hours solely on limited dates. Moreover, among motivation factors, debate existed regarding museums' priorities concerning education, leisure, and socializing. Comparing visitors' motivations for Museum Lates with daily activities and daytime operating hours, the study found several 
differences, such as cultural appreciation, education, entertainment, socializing, and convenience, differed from day-to-day activities and opening hours.Finally, there were limitations, such as an issue of sample selections. The study conducted the interviews mostly in one institution, which was NHM. During the limited period of data collection, the museum offered more events than the other institutions, and specialized attachment toward the venue found from diverse interviewees. Nevertheless, this study might bring pragmatic insight into institutions to attract more visitors by enhancing their satisfaction. The study made implications for managing and marketing the museum. The characteristics of Museum Lates enhance engagement, positive word-of-mouth, and the desire to return in the future. Managers should be aware that museums are an essential attraction for visitors and play a critical role in cultural tourism, providing educational programs and exhibitions that highlight the human-nature relationship and shape people's values, attitudes, and behaviors. The determination of which markets to include museums might be essential to understand the motivation behind visiting Museum Lates. Future research should identify the cultural sustainability of Museum Lates, which preserve, collect, research, and exhibit cultural artifacts.

\section{Reference}

Allen, J., Harris, R., McDonnell, I. and O'Toole, W. (2011). Festival and special event management. $5^{\text {th }}$ edition. Milton, Qld: Wiley.

Attride-Stirling, J. (2001). Thematic networks: an analytic tool for qualitative research. Qualitative research, 1(3), 385-405.

Axelsen, M. (2006). Using special events to motivate visitors to attend art galleries. Museum Management and Curatorship, 21(3), pp.205-221.

Axelsen, M. (2007). Visitors' Motivations to Attend Special Events at Art Galleries: An Exploratory Study. Visitor Studies, 10(2), pp.192-204.

Axelsen, M., Arcodia, C., \& Swan, T. (2006). New directions for art galleries and museums: The use of special events to attract audiences, a case study of the Asia Pacific Triennial. HTL Science, 3, 1-24.

Berg, B. and Lune, H. (2012). Qualitative research methods for the social sciences. $8^{\text {th }}$ edition. Harlow, Essex: Pearson.

Bertacchini, E.E.; Dalle Nogare, C.; Scuderi, R. Ownership, organization structure and public service provision: the case of museums. Journal of Cultural Economics, 2018, 42, 619-643.

Bjeljac, Z., Brankov, J. and Lukić, V. (2011). The 'Museum Night' Event - the Demographic Profile of the Visitors in Serbia. $f g, X(2)$, pp.229-234.

Bradburne, J. (2001). A New Strategic Approach to the Museum and its Relationship to Society. Museum Management and Curatorship, 19(1), pp.75-84.

Bryman, A. (2016). Social research methods. Oxford university press.

Christianson, M., Farkas, M., Sutcliffe, K. and Weick, K. (2009). Learning through Rare Events: Significant Interruptions at the Baltimore \& Ohio Railroad Museum. Organization Science, 20(5), pp.846-860.

Cima, J. (2012). Private Events, Public Spaces: Why Guests Choose Museums as Hosting Sites a Case Study at the Museum of Flight.

Collier, D., and Elman, C. (2008). Qualitative and multi-method research: Organizations, publication, and reflections on integration. In J. M. Box Steffensmeier, H. E. Brady, \& D. Collier (Eds.), The Oxford handbook of political methodology (pp. 779-795). Oxford, UK: Oxford University Press.

Deborah Wythe. (2004), Museum Archives: An Introduction, $2^{\text {nd }}$ edition, Society of American Archivists, Chicago.

DiMaggio, P. (1996). Are art-museum visitors different from other people? The relationship between attendance and social and political attitudes in the United States. Poetics, 24(2-4), pp.161-180.

Falk, J.H. (2013). Understanding Museum Visitors' Motivations and Learning. Museums: Social Learning Spaces and Knowledge Producing Processes, Arken-Museum of Modern Art, Denmark.

Falk, J. H., \& Dierking, L. D. (1992). The museum experience. Washington, DC: Whalesback Books. 
Falk, J.H. and Dierking, L.D. (2000). Learning from museums: Visitor experiences and the making of meaning. Altamira Press.

Falk, J.H and Dierking, L.D (2012). Museum Experience Revisited. Walnut Creek: Left Coast Press.

Freeland, C. (2001). But is it art?. Oxford: Oxford University Press.

Getz, D. (2005). Event management $\mathcal{E}$ event tourism. $2^{\text {nd }}$ edition. New York: Cognizant Communication Corporation.

Getz, D. and Page, S.J. (2016). Event studies: Theory, research and policy for planned events. $2^{\text {nd }}$ edition. Routledge.

Gordin, V. and Dedova, M. (2014). Cultural Innovation and Consumer Behaviour:

The Case of Museum Night. $f g, 16(2)$, pp.32-41. International Journal of Management Cases

Hein, G.E. (1998). Learning in the museum. London: Routledge.

Hein, G.E. (2005). The role of museums in society: education and social action. Unpublished paper presented at Fundação Casa de Rui Barbosa.

Huang, C. and Lin, F. (2013). Exploring Visitors' Experiential Experience in the Museum.

Hudson, K. (1998). The Museum Refuses to Stand Still. Museum International, 50(1), pp.43-50.

Hughes, H. (2000). Arts, entertainment and tourism. Oxford: Butterworth-Heinemann.

Straalen (Eds.), Economics and historic preservation (pp. 139-147). Akron, OH: Association for Cultural Economics.

Hooper-Greenhill, E. (1994). Museums and their visitors. London: Routledge.

Hooper-Greenhill, E. (2000). Changing Values in the Art Museum: rethinking communication and learning. International Journal of Heritage Studies, 6(1), pp.9-31.

Janes, R. R., \& Conaty, G. T. (2005). Looking Reality in the Eye: Museums and Social Responsibility.

Jansen-Verbeke, M. and van Rekom, J. (1996). Scanning museum visitors. Annals of Tourism Research, 23(2), pp.364-375.

Julia, H. (1997). Museums and touristic expectations. Annals of Tourism Research, 24(1), pp.23-40.

Kawashima, N. (1998). Knowing the Public. A Review of Museum Marketing Literature and Research1. Museum Management and Curatorship, 17(1), pp.21-39.

Kelley, K. (2012). Movement and Theater in the Art Museum. University of Oregon.

Kinghorn, N. and Willis, K. (2008). Measuring Museum Visitor Preferences towards Opportunities for Developing Social Capital: An Application of a Choice Experiment to the Discovery Museum. International Journal of Heritage Studies, 14(6), pp.555-572.

Kirezli, O. (2011). Museum Marketing: Shift from Traditional to Experiential Marketing. International Journal of Management Cases, 13(4), pp.173-184.

Kotler, N. and Kotler, P. (2000). Can Museums be All Things to All People?: Missions, Goals, and Marketing's Role. Museum Management and Curatorship, 18(3), pp.271-287.

Marshall, MN. (1996) Sampling for qualitative research. Family Practice; 13: 522-525.

Matthews, D. (2008). Special event production. The process. Amsterdam: Elsevier Butterworth-Heinemann.

Mavrin, I. and Glavaš, J. (2014). The Night of the Museums Event and Developing New Museum AudienceFacts and Misapprehensions on a Cultural Event. Interdisciplinary Management Research, 10, pp.265-274.

McIntyre, C. (2009). Museum and art gallery experience space characteristics: an entertaining show or a Contemplative bathe?. International Journal of Tourism Research, 11(2), pp.155-170.s

McManus, P. (1993). Memories as indicators of the impact of museum visits.

Museum Management and Curatorship, 12(4), pp.367-380.

Merriman, N. (2008) Museum collections and sustainability, Cultural Trends, 17:1, 3-21, DOI: $10.1080 / 09548960801920278$

Mokhtar, M. F., \& Kasim, A. (2011). Motivations for visiting and not visiting museums among young adults: A case study on UUM students. Journal of Global Management, 3(1), 43-58.

Mulholland, P., Wolff, A. Collins T. and Zdrahal, Z. (2011) 'An event-based approach to describing and understanding museum narratives', Proceedings: Detection, Representation, and Exploitation of Events in the Semantic Web Workshop in conjunction with the International Semantic Web Conference, Bonn, Germany.

Museumsatnight.org.uk. (2019). What's on I Museums at Night. [Online] Available at:

http://museumsatnight.org.uk/whats-on/\#.VxOBgfkrKM8 [Accessed 10 Apr. 2019].

Nelson, K. B. (2009, June). Enhancing the attendee's experience through creative design of the event environment: applying Goffman's dramaturgical perspective. In Journal of Convention E Event Tourism (Vol. 10, No. 2, pp. 120-133). Taylor \& Francis Group.

Nhm.ac.uk. (2019). Lates I Natural History Museum. [Online] Available at: http://www.nhm.ac.uk/visit/exhibitions/lates.html [Accessed 30 Aug. 2019]. 
Opdenakker, R. (2006). Advantages and disadvantages of four interview techniques in qualitative research. In Forum Qualitative Sozialforschung/Forum: Qualitative Social Research (Vol. 7, No. 4).

Packer, J., \& Ballantyne, R. (2002). Motivational factors and the visitor experience: A comparison of three sites. Curator: The Museum Journal, 45(3), 183-198.

Pencarelli, T.; Cerquetti, M.; Splendiani, S. The sustainable management of museums: an Italian perspective. Tourism and Hospitality Management, 2016, 22, 29-46.

Rowley, J. (1999). Measuring total customer experience in museums. Int J Contemp Hospitality Mngt, 11(6), pp.303-308.

Saunders, M., Lewis, P. and Thornhill, A. (2012). Research methods for business students. Harlow (Essex): Pearson.

Sciencemuseum.org.uk. (2019). Lates. [Online] Available http://www.sciencemuseum.org.uk/visitmuseum/plan_your_visit/lates [Accessed 1 Sep. 2019].

Smith, J. and Wolf, L. (1996). Museum visitor preferences and intentions in constructing aesthetic experience. Poetics, 24(2-4), pp.219-238.

Suarez, A.V. and Tsutsui, N.D. (2004). The value of museum collections for research and society. BioScience 54 (1), 66-74.

Tansuchat, R. and Panmanee, C. (2010). TOURIST MOTIVATION, CHARACTERISTIC, AND SATISFACTION IN NIGHT FESTIVAL: LOYKRATHONG FESTIVAL 2010. Published by: School of Tourism DevelopmentMaejo University, Thailand and Asian Tourism Management Association, 130.

Tate. (2019). Late at Tate Britain. [Online] Available at: http://www.tate.org.uk/whats-on/tate-britain/late/latetate-britain [Accessed 30 Aug. 2019].

Templeton, Cheryl A. (2011) "Museum Visitor Engagement through Resonant, Rich and Interactive Experiences".Theses. Paper 16.

Thomas, D. R. (2006). A general inductive approach for analyzing qualitative evaluation data. American journal of evaluation, 27(2), 237-246.

Turner D. (2010). Qulitative Interview Design: A practical Guide for Novice Investigators. The Qualitative Report. Vol. 15-3 (753-760).

Van Aalst, I. and Boogaarts, I. (2002). From Museum to Mass Entertainment: The Evolution of the Role of Museums in Cities. European Urban and Regional Studies, 9(3), pp.195-209.

Vassiliadis, C. and Belenioti, C. (2015). Branding in the New Museum Era. Research Gate.

Vaughan, R. (2001). Images of a Museum. Museum Management and Curatorship, 19(3), pp.253-268.

Vam.ac.uk. (2019). Friday Late - Victoria and Albert Museum. [Online] Available at: http://www.vam.ac.uk/content/articles/f/friday-late/ [Accessed 18 Apr. 2019].

Weil, S. (1997). The Museum and the public. Museum Management and Curatorship, 16(3), pp.257-271.

Wendroff, A.L., (2004). Special events: proven strategies for nonprofit fundraising. John Wiley \& Sons.

White, M.D., \& Marsh, E.E. (2006). Content analysis: A flexible methodology. Library Trends, 55(1), 22-45, doi: 10.1353/lib.2006.0053

Wilburn, M. (2007). Managing the customer experience: A measurement-based approach. ASQ Quality Press.

Worts, D. (2006) Measuring Museum Meaning, Journal of Museum Education, 31:1, 41-49, DOI: $10.1080 / 10598650.2006 .11510528$ 